The second option is to support in-country training; ODA for example is setting up research fellowships in the developing world.

A third option, which would lead to a more fertile exchange of ideas and moreover increase awareness of cross-cultural and global issues in Western psychiatrists, is to set up secondment schemes between centres. Postgraduate psychiatrists (senior registrar level in UK) could contribute to training, boost manpower and morale, and with backing from their home base facilitate research. A three year secondment would be the minimum on account of the adaptation required. In return, developing country psychiatrists might find overseas experience more meaningful after basic training in their relevant environment. WHO, ODA and the Commonwealth Secretariat have expressed an interest in such schemes.

The Maudsley Hospital

E. A. GuINNESS

London SE5 $8 A Z$

Institute of Psychiatry

Raj Persaud

London SE5 8 AF

\section{Psychiatry and philosophy}

DeAR Sirs

Morris's statement (Psychiatric Bulletin, May 1992, 16, 294-295) that the two opposing theoretical positions in psychiatry (the psychodynamic and the biological) "are part of a fundamental debate running through the history of philosophy, between the traditions in the philosophy of metaphysics of materialism and idealism" is a dogmatic assertion, unsupported by evidence or argument. There are no conceptual or historical connections between these two positions and the debates surrounding the idealism/realism issue in the history of philosophy. The practice of clinical psychiatry is based upon acceptance of the existence of such phenomena as mental processes, psycho-social structures, cerebral pathology and neuro-chemical changes. The clinician or research worker adopts the stance characterised by the philosopher as 'common-sense realism'. Philosophical reflection upon this basic position/ 'experience of the world' can complicate matters by showing that its ultimate analysis can lead to the philosophical theses of either metaphysical idealism or metaphysical realism. Thus, common-sense realism can not only be extended (by philosophical considerations) to a form of metaphysical realism (or naturalism or materialism) but shown to be fully compatible with metaphysical idealism (Acton, 1967).

Philosophical idealism of the traditional variety has no serious adherents in contemporary philosophy. Many different kinds of realism compete today in the philosophical marketplace: the 'scientific realism' of many philosophers of science, the
'Realism with a Human Face' of Hilary Putnam and the 'transcendental realism' of phenomenologists.

The most serious lacuna in Morris's account is the failure to mention the major philosophical school of phenomenology. Its two divergent manifestations the 'transcendental phenomenology' of Husserl and the 'fundamental ontology' of Heidegger - are based on a fundamental conviction and claim to have definitively overcome the ages-old dichotomy of idealism/ realism-this is the source of their philosophical interest. Philosophical phenomenology has had a decisive impact on the theory and practice of psychiatry, psychology and psychotherapy on the European continent and North America but only marginally so in Britain.

In their extreme forms the two opposed views (psychodynamic and biological) are related to the central issue of whether the focus is on human beings as persons or as (biological) organisms. Although this conceptual polarity is deeply embedded in our modern 'scientific' culture, I do not think it is related to the idealism/realism debate, rather a reflection of tendencies and thought-patterns which have been developing in our culture over the past three hundred years. The exploration of these issues has now become a matter of urgent importance.

\section{Salman Rashid}

\section{The Royal Oldham}

Hospital Trust

Oldham OL1 $2 \mathrm{JH}$

\section{Reference}

Acton, H. B. (1967) Idealism, The Encyclopaedia of Philosophy London: Collier-Macmillan. Volume 4, pp 110-118.

\section{Reply}

\section{DEAR SIRS}

I welcome with interest Dr Raschid's contribution, in particular his clarification of "materialism" as a type of philosophical realism. I think we are fundamentally in agreement, that there is a conceptual polarity in psychiatry the patient being a "person" or an "organism". I believe that the philosophical expression of these cultural thought patterns is the idealist/realist debate; another incarnation is the mind/body debate. Dr Raschid disagrees, although he does not argue this position.

Phenomenology argues that it is only those things that are directly available to experience that can be studied. Sadly for biological psychiatry, however, this rules out such notions as dopamine receptors and monoamine reuptake inhibitors. There is nothing in a phenomenological metaphysic to decide whether the "Dasein" (being-in-the-world) of the patient who believes the CIA control his brain is any more or less valid than the "Dasein" of the psychiatrist who believes 